\title{
Early adaptation to oxygen is key to the industrially important traits of Lactococcus lactis ssp. cremoris during milk fermentation
}

Marina Cretenet ${ }^{2,3,4}$, Gwenaëlle Le Gall', Udo Wegmannn', Sergine Even ${ }^{2,3}$, Claire Shearman ${ }^{5}$, Régis Stentz ${ }^{1}$ and Sophie Jeanson ${ }^{1,2,3,6^{*}}$

\begin{abstract}
Background: Lactococcus lactis is the most used species in the dairy industry. Its ability to adapt to technological stresses, such as oxidative stress encountered during stirring in the first stages of the cheese-making process, is a key factor to measure its technological performance. This study aimed to understand the response to oxidative stress of Lactococcus lactis subsp. cremoris MG1363 at the transcriptional and metabolic levels in relation to acidification kinetics and growth conditions, especially at an early stage of growth. For those purposes, conditions of hyper-oxygenation were initially fixed for the fermentation.

Results: Kinetics of growth and acidification were not affected by the presence of oxygen, indicating a high resistance to oxygen of the L. lactis MG1363 strain. Its resistance was explained by an efficient consumption of oxygen within the first 4 hours of culture, leading to a drop of the redox potential. The efficient consumption of oxygen by the L. lactis MG1363 strain was supported by a coherent and early adaptation to oxygen after 1 hour of culture at both gene expression and metabolic levels. In oxygen metabolism, the over-expression of all the genes of the $n r d$ (ribonucleotide reductases) operon or fhu (ferrichrome ABC transports) genes was particularly significant. In carbon metabolism, the presence of oxygen led to an early shift at the gene level in the pyruvate pathway towards the acetate/2,3-butanediol pathway confirmed by the kinetics of metabolite production. Finally, the MG1363 strain was no longer able to consume oxygen in the stationary growth phase, leading to a drastic loss of culturability as a consequence of cumulative stresses and the absence of gene adaptation at this stage.
\end{abstract}

Conclusions: Combining metabolic and transcriptomic profiling, together with oxygen consumption kinetics, yielded new insights into the whole genome adaptation of L. lactis to initial oxidative stress. An early and transitional adaptation to oxidative stress was revealed for L. lactis subsp. cremoris MG1363 in the presence of initially high levels of oxygen. This enables the cells to maintain key traits that are of great importance for industry, such as rapid acidification and reduction of the redox potential of the growth media.

Keywords: Lactococcus lactis, Transcriptomics, Metabolomics, Stress response, Oxidative stress, Redox potential, Acidification, Growth

\footnotetext{
* Correspondence: sophie.jeanson@rennes.inra.fr

${ }^{1}$ Institute of Food Research, Norwich Research Park, Colney, Norwich NR4

7UA, UK

${ }^{2}$ INRA, UMR1253, F-35000 Rennes, France

Full list of author information is available at the end of the article
} 


\section{Background}

Lactic acid bacteria (LAB) are historically defined as microaerophilic, Gram-positive organisms that produce lactic acid during homo- or heterofermentative metabolism of carbohydrates. Their ability to ferment hexoses makes them of great use in industrial applications to transform milk, meats and vegetables into fermented products. Their biosynthetic pathways are at the origin of a variety of flavors, textures and preservative qualities of fermented foods. Industrial applications of LAB rely on six key beneficial and nonpathogenic species [1]. Among them, Lactococcus lactis is the main source of mesophilic starter strains used for the production of different kinds of cheeses, fermented milks and cultured butter. The great economic importance of this species makes it a significant bacterial model for the study of anaerobic sugar catabolism $[2,3]$. The formation of lactic acid from lactose, of diacetyl from citrate and its proteolytic activity are the three main lactococcal traits of interest for milk fermentation and aroma compound formation in dairy products, notably the underlying genes for these traits are all plasmid encoded.

L. lactis strains are divided in two subspecies designated as L. lactis subsp. lactis and L. lactis subsp. cremoris [4]. As an excellent model for research on bacterial metabolism and for the development of new applications, L. lactis genomics developed quickly with the availability of the first complete genome sequence of Lactococcus strain, $L$. lactis lactis IL1403 [5]. Currently, eleven complete L. lactis genomes are available with six strains belonging to the subspecies lactis and five to the subspecies cremoris. The complete genomic sequence of $L$. lactis subsp. cremoris MG1363 was released by Wegmann et al. [6] and revised by Linares et al. [7]. Most L. lactis mutants have been constructed from strain MG1363 and its derivatives. Many studies using these mutants focused on studying hemerespiration [8-10] or carbohydrate metabolism [11,12] but few give global transcriptome profiles in response to environmental stresses. Recently, Carvalho et al. [13] presented the effect of acid stress on the glucose metabolism of nongrowing cells of L. lactis MG1363 using nuclear magnetic resonance (NMR) and microarrays and De Jong et al. [14] performed temporal transcriptome analysis during growth of L. lactis MG1363 in milk. Global transcriptomic analysis in response to technological stresses, e.g. acidification and oxygen, have mostly been performed on strain IL1403 and its derivatives [15-19]. Specific studies of L. lactis MG1363 are still needed to be able to understand its responses to technological stresses.

Many physiochemical parameters, such as temperature, $\mathrm{pH}$, water activity and pressure, affect L. lactis metabolism during cheese manufacture and are measured for quality control purposes. Additional parameters, such as the oxido-reduction potential, called redox potential $\left(E_{h}\right)$, and the concentration of dissolved oxygen [20], are of growing interest to the dairy industry. The concentration of dissolved oxygen is exponentially correlated to the redox potential [21] and changes constantly during cheese manufacturing. Oxygen is especially present at the very beginning of growth, when the milk is pumped and then stirred before coagulation. It has been shown that high initial levels of dissolved oxygen in milk can drastically delay acidification by Lactococcus starter strains [22,23]. Cachon et al. [24] observed that L. lactis reduces milk prior to acidification. Reduction of milk by L. lactis is due both to oxygen consumption and a decrease of redox potential when oxygen disappears. Experimental data and genomic analyses indicate that L. lactis is able to cope with oxidative stress in a similar way to the aerobic model bacteria Escherichia coli and Bacillus subtilis [25-27]. L. lactis is relatively tolerant to oxygen and shows a great capacity to adapt to an oxygenated environment. In the presence of oxygen and heme, L. lactis is even able to respire and as a result, cell survival is improved and population is increased [8]. However, these heme conditions do not occur naturally. In an aerated environment, L. lactis is able to consume oxygen, resulting in an altered redox state and in a shifted carbon metabolism towards mixed fermentation [28]. However, studying the literature, several knowledge gaps can be identified, e.g. no study focused on the early exponential phase of growth when starter strains are exposed to oxidative stress, and no study took into account the redox potential values and the dissolved oxygen concentrations in relation to growth kinetics, metabolomic and transcriptomic data.

The aim of this study was to understand the adaptation of $L$. lactis to an initial oxidative stress, as encountered during the cheese-making process, at the transcriptional and metabolic levels in relation to the acidification kinetics and growth conditions. Whole genome transcriptome analysis of L. lactis MG1363 was performed at four time points $(1,5,8$ and $24 \mathrm{~h}$ of culture) during a $24 \mathrm{~h}$ period of growth and combined with a time-course quantitative analysis of produced metabolites by nuclear magnetic resonance (NMR) spectroscopy. A derivative of L. lactis MG1363, carrying the pLP712 plasmid, was grown in a medium containing lactose under two oxygen conditions: initial hyper-oxygenized medium (O2), to mimic the environment of a cheese-making process, and in oxygen-depleted medium (N2).

\section{Results}

Lactococcus lactis MG1363 underwent a drastic loss of culturability in condition $\mathrm{O} 2$

The kinetics of growth (OD and enumerations), acidification $(\mathrm{pH})$, reduction $\left(\mathrm{E}_{\mathrm{h} 7}\right)$ and dissolved oxygen consumption (dissolved oxygen concentration) were monitored over $24 \mathrm{~h}$ for two conditions: initial hyper-oxygenized 
condition (O2) and no oxygen condition (N2) (Figure 1). Despite completely different gas conditions, no differences could be observed during the exponential growth phase, while substantial differences in culturability could be observed during the stationary growth phase. We defined 4 stages based on the oxygen concentration during growth under condition $\mathrm{O} 2$ (Figure 1). In stage $\mathrm{A}$, the medium was initially saturated with oxygen (Figure 1.1) and the bacteria were in the early exponential growth phase (Figure 1.2), with minor changes in the $\mathrm{pH}$ (Figure 1.3) and the redox potential (Figure 1.1). In stage B, oxygen had totally been consumed and both culture media (under conditions $\mathrm{O} 2$ and N2) were anaerobic; bacteria were between midand late-exponential growth phase, the rate of acidification was at a maximum level and the redox potential decreased drastically since the oxygen concentration dropped abruptly to $0 \%$. Until the strain MG1363 reached the stationary growth phase, its kinetics of growth and

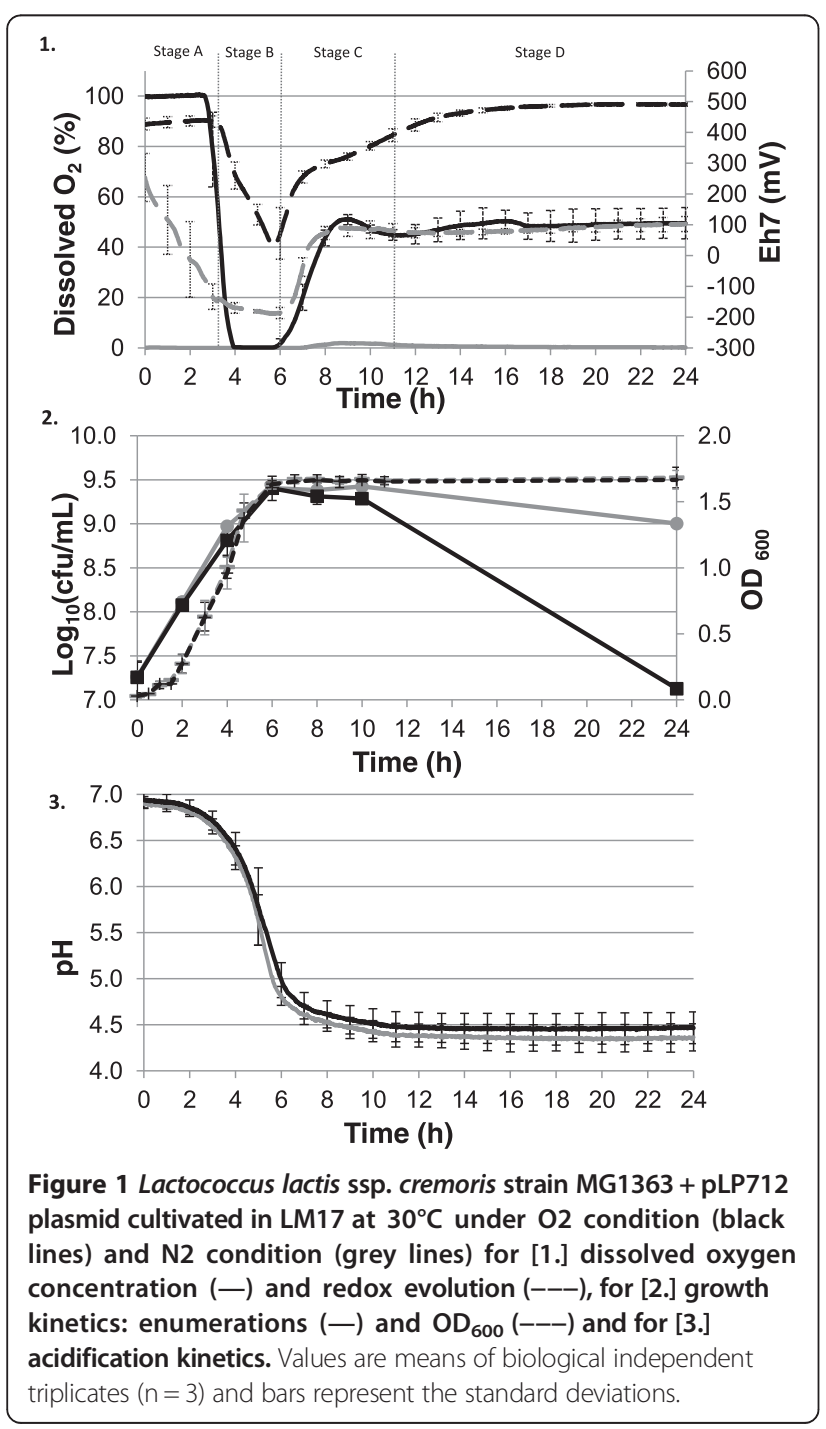

acidification was not affected by oxygen. Stage C started when the cells entered the early stationary growth phase reaching the maximum population density; acidification kinetics in conditions $\mathrm{O} 2$ and $\mathrm{N} 2$ were superimposed until a minimum $\mathrm{pH}$ was reached. In contrast to condition $\mathrm{N} 2$, the oxygen concentration in condition $\mathrm{O} 2$ increased again up to $50 \%$, leading in turn to an increased redox potential. This increase of oxygen occurred because the bioreactor head-space was still filled with pure oxygen which dissolved into the LM17 medium and was presumably no longer consumed by the cells at this stage. Finally, during stage D the dissolved oxygen concentration stabilized at $50 \%$ of the initial value in condition $\mathrm{O} 2$ while there was still no oxygen detectable in condition N2. The L. lactis MG1363 was then in the late stationary growth phase, the minimum $\mathrm{pH}$ was reached (4.4 for condition $\mathrm{N} 2$ and 4.5 for condition $\mathrm{O} 2$ ) and the redox potential was stable $(+100 \mathrm{mV}$ for condition $\mathrm{N} 2$ and $+490 \mathrm{mV}$ for condition $\mathrm{O} 2$ ). The main difference between the two conditions occurred during this stage: the culturability loss was much higher under condition $\mathrm{O} 2\left(-2 \log _{10} \mathrm{CFU} \mathrm{ml} \mathrm{m}^{-1}\right)$ than under condition $\mathrm{N} 2\left(-0.5 \log _{10} \mathrm{CFU} \mathrm{ml}{ }^{-1}\right)$.

\section{Predominance of differentially expressed genes at $1 \mathrm{~h}$ in} the time-course analysis of L. lactis MG1363 transcriptome Transcriptomic analysis was performed on the whole genome of strain MG1363. Differentially expressed (DE) genes in condition $\mathrm{O} 2$ in comparison to condition N2 were determined at different time points corresponding to stage A $(1 \mathrm{~h})$, stage B $(5 \mathrm{~h})$, stage C $(8 \mathrm{~h})$ and stage D $(24 \mathrm{~h})$. All DE genes are described in the supplementary data (Additional file 1: Table S1) and DE genes discussed in the text are gathered in Table 1. Figure 2 represents the number of DE genes per known COG category, for each time point except $24 \mathrm{~h}$ (only one DE gene). The adaptation to oxygen strikingly occurred at $1 \mathrm{~h}$ (Figure 2.1) of culture (53 genes over-expressed and 37 genes underexpressed). All the COG categories were represented, indicating a global adaptation to oxidative stress. Moreover, COG categories $\mathrm{C}$ (energy production and conversion), $\mathrm{E}$ (amino acid transport and metabolism), F (nucleotide transport and metabolism) and $\mathrm{O}$ (post-transcriptional modification, protein turnover and chaperone) were specifically over-expressed in condition $\mathrm{O} 2$, clearly indicating that the cellular and energetic mechanisms were particularly affected at this early stage of growth. Only a small number of DE genes were observed at $5 \mathrm{~h}$ (Figure 2.2), most of which (11 out of 13) were under-expressed, probably because during stage $B$ the absence of oxygen led to similar oxygen environment in both conditions $\mathrm{O} 2$ and N2, between 4 and $6 \mathrm{~h}$ of culture. In stage C (Figure 2.3), while dissolved oxygen increased again in the condition $\mathrm{O} 2$, only 23 genes were $\mathrm{DE}$, of which 21 were underexpressed, indicating that the gene adaptation to oxygen 
Table 1 Genes over- and under-expressed under oxygen conditions (condition 02) for the strain MG1363

\begin{tabular}{|c|c|c|c|c|c|c|c|}
\hline NomSpot & $\begin{array}{c}\text { COG } \\
\text { number }\end{array}$ & $\begin{array}{l}\text { COG functional } \\
\text { categories }\end{array}$ & $\begin{array}{l}\text { Gene } \\
\text { name }\end{array}$ & Gene product & $1 \mathrm{~h}$ & $5 \mathrm{~h}$ & $8 \mathrm{~h}$ \\
\hline IImg_1464 & COG3527 & Q & aldC & alpha-acetolactate decarboxylase & 4.59 & & \\
\hline Ilmg_1309 & COG0028 & $\mathrm{EH}$ & als & acetolactate synthase large subunit & 3.64 & & \\
\hline Ilmg_1700 & COG4608 & $\mathrm{E}$ & choQ & choline ABC transporter ATP binding protein & 3.21 & & \\
\hline Ilmg_1699 & COG1732 & M & chos & choline $A B C$ transporter permease and substrate binding protein & 3.61 & & \\
\hline Ilmg_1737 & COG0596 & $\mathrm{R}$ & $c p o$ & non-heme chloride peroxidase & 2.27 & & \\
\hline Ilmg_0346 & COG1118 & $\mathrm{P}$ & fhuc & ferrichrome $A B C$ transporter fhuC & 4.28 & & \\
\hline Ilmg_0349 & COG0614 & $\mathrm{P}$ & fhuD & ferrichrome $A B C$ transporter substrate binding protein & 5.67 & & \\
\hline Ilmg_0348 & COG0609 & $P$ & fhuG & ferrichrome $A B C$ transporter permease protein & 4.15 & & \\
\hline Ilmg_1702 & COG1249 & $C$ & $\operatorname{gsh} R$ & glutathione reductase & 3.00 & & \\
\hline IImg_0274 & & & Ilmg_0274 & conserved hypothetical protein & 4.67 & & \\
\hline Ilmg_0276 & COG0656 & $\mathrm{R}$ & Ilmg_0276 & oxidoreductase, aldo/keto reductase family & 3.52 & & \\
\hline IImg_0281 & COG1328 & $\mathrm{F}$ & Ilmg_0281 & anaerobic ribonucleoside-triphosphate reductase & 6.11 & & \\
\hline IImg_2143 & COG1302 & $\mathrm{S}$ & llmg_2143 & putative $20-k$ Da protein & 3.24 & & \\
\hline Ilmg_2144 & & & llmg_2144 & hypothetical protein predicted by Glimmer/Critica & 5.30 & & \\
\hline IImg_2145 & & & llmg_2145 & conserved hypothetical protein & 5.27 & & \\
\hline Ilmg_0075 & COG0095 & $\mathrm{H}$ & Ip/L & lipoate-protein ligase & 8.38 & & \\
\hline IImg_1828 & COG1169 & $\mathrm{HQ}$ & menF & menaquinone-specific isochorismate synthase & 2.69 & & \\
\hline |lmg_0951 & COG0225 & $\mathrm{O}$ & $m s r A$ & peptide methionine sulfoxide reductase & 2.52 & & \\
\hline Ilmg_1970 & COG0822 & C & nifU & conserved hypothetical protein & 4.33 & & \\
\hline IImg_0408 & COG0446 & $\mathrm{R}$ & noxE & NADH oxidase & 22.93 & & \\
\hline Ilmg_1543 & COG0209 & $\mathrm{F}$ & nrdE & ribonucleoside-diphosphate reductase alpha chain & 16.70 & & \\
\hline IImg_1544 & COG0208 & $\mathrm{F}$ & $n r d F$ & ribonucleoside-diphosphate reductase beta chain & 5.63 & & \\
\hline |lmg_0282 & COG0602 & $\mathrm{O}$ & $\operatorname{nrdG}$ & anaerobic ribonucleoside-triphosphate reductase activating protein & 4.30 & & \\
\hline Ilmg_1541 & COG0695 & $\mathrm{O}$ & $n r d H$ & Glutaredoxin-like protein nrdH. & 10.25 & & \\
\hline Ilmg_1542 & COG0716 & C & $n r d l$ & Ribonucleotide reductase $\mathrm{Nrdl}$ & 12.93 & & \\
\hline Ilmg_0074 & COG1071 & C & $p d h A$ & pyruvate dehydrogenase E1 component alpha subunit & 5.96 & & \\
\hline Ilmg_0073 & COG0022 & C & $p d h B$ & pyruvate dehydrogenase E1 component beta subunit & 5.03 & & \\
\hline Ilmg_0072 & COG0508 & C & $p d h C$ & pyruvate dehydrogenase complex E2 component & 5.65 & & \\
\hline Ilmg_0071 & COG1249 & C & $p d h D$ & pyruvate dehydrogenase complex E3 component & 2.84 & & \\
\hline Ilmg_0629 & COG1882 & C & $p f l$ & formate acetyltransferase & & 2.97 & \\
\hline Ilmg_0318 & COG2077 & $\mathrm{O}$ & $t p x$ & thiol peroxidase & 4.18 & & \\
\hline Ilmg_0776 & COG0492 & $\mathrm{O}$ & $\operatorname{tr} \times B 2$ & thioredoxin reductase & 4.28 & & \\
\hline NomSpot & $\begin{array}{c}\text { COG } \\
\text { number }\end{array}$ & $\begin{array}{l}\text { COG functional } \\
\text { categories }\end{array}$ & $\begin{array}{l}\text { Gene } \\
\text { name }\end{array}$ & Gene product & $1 \mathrm{~h}$ & $5 \mathrm{~h}$ & $8 \mathrm{~h}$ \\
\hline IImg_2432 & COG1012 & C & adhe & alcohol-acetaldehyde dehydrogenase & -7.45 & & \\
\hline Ilmg_0100 & COG2217 & $\mathrm{P}$ & $\operatorname{cadA}$ & cation-transporting ATPase & -4.06 & & \\
\hline Ilmg_1865 & COG3104 & $\mathrm{E}$ & $d t p T$ & di-/tripeptide transporter & -2.11 & & \\
\hline Ilmg_0758 & COG0038 & $P$ & eric & Putative chloride channel protein. & -2.04 & & \\
\hline Ilmg_1551 & COG2116 & $\mathrm{P}$ & $f d h C$ & putative formate dehydrogenase & -2.76 & & \\
\hline Ilmg_1441 & COG1053 & C & frdC & fumarate reductase flavoprotein subunit & -4.24 & & \\
\hline Ilmg_0993 & COG0634 & $\mathrm{F}$ & hprT & hypoxanthine-guanine phosphoribosyltransferase & -2.01 & & \\
\hline Ilmg_1915 & COG0247 & C & Ilmg_1915 & putative Fe-S oxidoreductase & -3.61 & & \\
\hline Ilmg_0447 & COG0674 & $C$ & nifJ & $\begin{array}{l}\text { Pyruvate:ferredoxin oxidoreductase and related 2-oxoacid:ferredoxin } \\
\text { oxidoreductases, alpha subunit }\end{array}$ & -11.19 & & \\
\hline
\end{tabular}


Table 1 Genes over- and under-expressed under oxygen conditions (condition 02) for the strain MG1363 (Continued)

\begin{tabular}{|c|c|c|c|c|c|c|c|}
\hline Ilmg_1514 & COG2344 & R & rex & Redox-sensing transcriptional repressor rex. & -2.73 & & \\
\hline Ilmg_0640 & COG1393 & $P$ & $\operatorname{trm} A$ & Regulatory protein spx & -2.15 & & \\
\hline IImg_0429 & COG0605 & $P$ & sodA & superoxide dismutase & & -3.08 & \\
\hline Ilmg_1362 & & & orf44 & hypothetical protein predicted by Glimmer/Critica & & -2.28 & \\
\hline Ilmg_1376 & COG4227 & L & ItrC & LtrC & & & -2.61 \\
\hline Ilmg_1377 & & & orf30 & hypothetical protein predicted by Glimmer/Critica & & & -2.09 \\
\hline Ilmg_1378 & & & orf29 & hypothetical protein predicted by Glimmer/Critica & & & -2.10 \\
\hline Ilmg_1379 & COG2856 & $E$ & orf28 & Predicted Zn peptidase & & & -2.06 \\
\hline Ilmg_1384 & & & orf24 & hypothetical protein predicted by Glimmer/Critica & & & -2.11 \\
\hline Ilmg_1387 & COG5179 & K & orf21 & hypothetical protein predicted by Glimmer/Critica & & -2.12 & \\
\hline Ilmg_1399 & & & orf10 & hypothetical protein predicted by Glimmer/Critica & -2.37 & & \\
\hline IImg_1402 & & & orf8 & hypothetical protein predicted by Glimmer/Critica & & & -2.03 \\
\hline
\end{tabular}

Fold-changes of selected differentially expressed genes of the strain MG1363 in O2 condition in comparison with N2 condition, from a whole-genome microarray analysis $(n=3)$. Genes were significantly $(p$-value $<0.5)$ differentially expressed with a FDR $<0.5$ and a $\mid$ fold-change $\mid>2$. Top table is over-expressed genes; bottom table is under-expressed genes. Under-expressed genes; the ninth last genes are involved in the conjugation.

observed in stage A did not occur despite the presence of oxygen.

We will now focus on the main differences in gene expression between conditions $\mathrm{O} 2$ and N2, as determined by microarrays and further confirmed by quantitative real time PCR (RT-qPCR). The results are presented in Tables 1 and 2. Genes amplified by RT-qPCR were mainly selected as representatives of the key metabolic pathways activated or repressed in our experimental conditions in order to validate the global transcriptome analysis.

The carbon metabolism is shifted to aerobic metabolism at an early stage of growth under condition $\mathrm{O} 2$

As a type of homolactic bacteria, L. lactis produces mainly lactic acid from pyruvate, using glucose or lactose as carbon sources. However, other metabolites are simultaneously produced to a lesser extent from pyruvate using metabolic pathways dependent on culture conditions such as the oxygen level (Figure 3). Lactococcus lactis MG1363 displayed no differences in lactate dehydrogenase expression, under the two conditions $\mathrm{O} 2$ and N2. Besides this main pathway, the other pathways were affected under the condition O2. Genes pdhA-D, als and ald $C$, respectively encoding pyruvate dehydrogenase, acetolactate synthase, and alpha-acetolactate decarboxylase, were found to be over-expressed in condition $\mathrm{O} 2$ at $1 \mathrm{~h}$ (Table 1). Using RT-qPCR, genes $p d h A$ and aldC were also found to be over-expressed at $5 \mathrm{~h}$ and $8 \mathrm{~h}$ (Table 2). It should be noted that the gene $l p l L$, coding for a lipoateprotein ligase, which is adjacent to the $p d h$ genes, also displayed an over-expression. On the contrary, under condition $\mathrm{O} 2$, genes $a d h E$ and $f d h C$ (Table 1), respectively encoding alcohol acetaldehyde-dehydrogenase (AdhE) and formate dehydrogenase (FdhC), were under-expressed at $1 \mathrm{~h}$. The gene $p f l$, encoding pyruvate formate lyase (PFL), responsible for the carbon flux from pyruvate to the formate/ethanol pathway (Figure 3), was over-expressed at $5 \mathrm{~h}$ (Table 1) indicating a switch from the aerobic to the anaerobic metabolism (Figure 3) during stage B. Finally, the gene frdC, coding for a flavoprotein involved in the reduction of fumarate to succinate, was under-expressed at $1 \mathrm{~h}$.

As a consequence of this early adaptation at the gene level, the metabolism was different under the two conditions $3 \mathrm{~h}$ into growth for most of the minor products derived from lactose. The metabolomics analysis performed using NMR analysis allowed to identify 27 metabolites (3 were only identified at the compound family level). Among them, 5 metabolites of major importance in the carbon metabolism of Lactococcus lactis had different kinetics of consumption or production under the two conditions. Figure 4 shows their kinetics (with the addition of lactose and lactate) at 7 time points over the 24 h-period. Lactose was not totally consumed at the end of the culture and its kinetics of consumption was not significantly different between the two conditions. Lactate was the main fermentation product in both conditions, with yields reaching 1.62 and 1.45 mol lactate per $\mathrm{C}_{6-}$ mol of sugar consumed under conditions $\mathrm{O} 2$ and N2, respectively. On the contrary, minor products such as acetate, formate, ethanol and 2,3-butanediol displayed significantly different production kinetics under conditions $\mathrm{O} 2$ and $\mathrm{N} 2$ (Figure 4). While formate and ethanol were produced more under condition N2, acetate, 2,3-butanediol and acetoin were produced more under condition O2 (Figures 3 and 4). The differences in these kinetics were observable, at the 3 or $5 \mathrm{~h}$ time point, and increased steadily over the whole 24 h-period, except for acetoin, which was increasingly transformed into 2,3-butanediol from $5 \mathrm{~h}$ onwards. 
Figure 2 Gene expression of strain MG1363: differentially expressed genes (over- and under-expressed), in $\mathrm{O} 2$ condition in comparison to $\mathrm{N} 2$ condition grouped by COG categories (letters) at $\mathbf{1 ~ h , ~} \mathbf{5} \mathrm{h}, \mathbf{8} \mathrm{h}$ of culture in $\mathrm{LM} 17$ at $30^{\circ} \mathrm{C}$. COG categories: Information storage and processing $=>\mathrm{J}$ "Translation, ribosomal structure and biogenesis", K "Transcription", L "DNA replication, recombination and repair"; Cellular processes $=>$ D "Cell division and chromosome partitioning", O "Posttranslational modification, protein turnover, chaperones", M "Cell envelope biogenesis, outer membrane", P "Inorganic ion transport and metabolism", T "Signal transduction mechanisms", $U$ "Intracellular trafficking and secretion"; Metabolism = > C "Energy production and conversion", G "Carbohydrate transport and metabolism", E "Amino acid transport and metabolism", F "Nucleotide transport and metabolism", H "Coenzyme metabolism", I "Lipid metabolism", Q "Secondary metabolites biosynthesis, transport and catabolism"; Poorly characterized $=>$ R "General function prediction only", S "Function unknown".
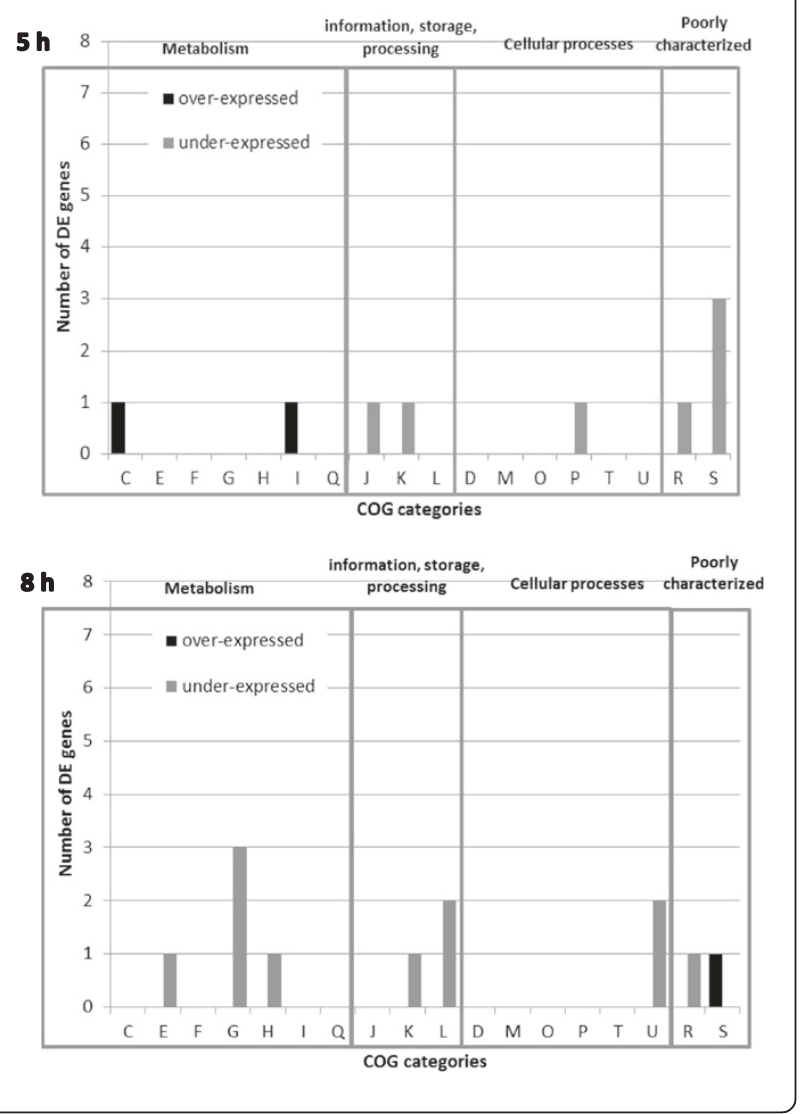

Genes involved in the response to oxidative stress were all DE early in the exponential phase, but not later Genes involved in the response to oxidative stress and in electron transport were predominantly and highly expressed at $1 \mathrm{~h}$ (Table 1). These genes code for proteins involved in oxygen detoxification, electron transport and maintenance of the cell's redox state. Among all, the gene which displayed the highest over-expression was noxE coding for the NADH oxidase responsible for the conversion of molecular $\mathrm{O}_{2}$ to $\mathrm{H}_{2} \mathrm{O}$. Over-expression of nox $E$ was confirmed by RT-qPCR at $1 \mathrm{~h}$ but not at 5 and $8 \mathrm{~h}$ (Table 2) indicating that this response only occurred in the early exponential phase. Genes involved in the transport of electrons displayed the same pattern: overexpression at $1 \mathrm{~h}$ but not later for gene menF involved in the synthesis of the menaquinone $C$ (vitamin K2) and 3 out of 4 genes of the $f h u$ operon coding for the ferrichrome $\mathrm{ABC}$ transporter (Table 1). However, high expression (14-fold) of the fhuD gene was confirmed by RT-qPCR at $1 \mathrm{~h}$ and to a lesser extent at $5 \mathrm{~h}$ and $8 \mathrm{~h}$ of culture (Table 2). The nucleotide reductases encoded by the $n r d$ genes were part of the early adaptive response to hyper-oxygenized conditions, as all six $n r d$ genes were over-expressed at $1 \mathrm{~h}$ with fold-changes ranging from 4to 16-fold. RT-qPCR confirmed over-expression of the $n r d H$ gene at $1 \mathrm{~h}$, and - but to a lesser extent - at 5 and $8 \mathrm{~h}$ (Table 2). Other genes such as the genes involved in the control of the redox state of the cell, e.g. reduction of thiols ( $\operatorname{tr} x B 2, t p x, m s r A)$, reductases (llmg_0276) or a non-heme chloride peroxidase $(c p o)$ which plays a role in the detoxification of hydrogen peroxide to water, were over-expressed at $1 \mathrm{~h}$.

Conversely, oxygen-sensitive genes such as nifJ and llmg 1915 were found to be under-expressed at $1 \mathrm{~h}$. Transport proteins were also under-expressed: cadA coding for a cation transporting ATPase, dtpT and eriC coding for di-/tri-peptide transporter and for chloride 
Table 2 Gene expression confirmed using RT-qPCR under oxygen conditions (condition 02)

\begin{tabular}{|c|c|c|c|c|c|c|c|c|c|c|}
\hline \multirow{3}{*}{ Locus tag } & \multirow{3}{*}{ Gene } & \multirow{3}{*}{ Gene product } & \multirow{3}{*}{$\begin{array}{c}\text { Primer sequences } \\
\text { Forward }\end{array}$} & \multirow[b]{3}{*}{ Reverse } & \multicolumn{6}{|c|}{$\begin{array}{l}\text { Ratio of gene expression 02/N2 } \\
\text { as determined by: }\end{array}$} \\
\hline & & & & & \multicolumn{3}{|c|}{ Transcriptome analysis } & \multicolumn{3}{|c|}{ RT-qPCR } \\
\hline & & & & & $1 \mathrm{~h}$ & $5 \mathrm{~h}$ & $8 \mathrm{~h}$ & $1 \mathrm{~h}$ & $5 \mathrm{~h}$ & $8 \mathrm{~h}$ \\
\hline IImg_0408 & noxE & NADH oxidase & TTATGCCAAAGCAGAgGATTT & GGAATAATTGGACGTGAACCTG & 22.9 & -3.2 & & 26.7 & 2.0 & \\
\hline IImg_0074 & pdhA & pyruvate dehydrogenase E1 component alpha subunit & AGGACGTATGGGATTCTTTGG & TTACCAAGTTGATGTCCACGAG & 6.0 & -2.3 & & 7.7 & 2.8 & 4.1 \\
\hline Ilmg_1541 & $\mathrm{nrdH}$ & Glutaredoxin-like protein nrdH. & AATTGTATGCAATGCAAAATGG & ATTACAGGAGCAGCTCGAAAAC & 10.3 & & 2.8 & 28.3 & 4.7 & 6.9 \\
\hline IImg_0776 & $\operatorname{trxB2}$ & thioredoxin reductase & TGGTCTtTATGCGGCTITITAt & GGTAAAGATTTGtGGCTGACC & 4.3 & & & 13.3 & 2.4 & \\
\hline Ilmg_2432 & adhE & alcohol-acetaldehyde dehydrogenase & GGTTCTGAAGTGACTCCATTTG & TCATAACAAACTCAGGGTCAACA & -7.5 & & & -8.55 & & \\
\hline Ilmg_1464 & adlC & alpha-acetolactate decarboxylase & GGCTGACCAACCTTATTTTACA & TTCaGTgATGAAATTTGGACA & 4.6 & & 3.7 & 11.8 & 2.3 & 4.8 \\
\hline Ilmg_1699 & chos & choline $A B C$ transporter permease & TाTGCAAGTCACaGGAATTITा & GGaAAAATCGCATAAACAACAAG & 3.6 & & & 10.0 & 4.1 & 3.1 \\
\hline Img2144 & Img2144 & conserved hypothetical protein & TtGGcGGAATaaTAGGctgt & cGTgCgtTgaAgAtAgAGACC & 5.3 & -4.3 & & 9.0 & & 2.7 \\
\hline Img0274 & Img0274 & conserved hypothetical protein & CTCggTCATcGGAAAAGAAG & TtGTaGCTgcTGCCAGAG & 4.7 & 2.3 & 2.4 & 5.3 & & \\
\hline Ilmg_0100 & $\operatorname{cadA}$ & cation-transporting ATPase & TITGGCTTAAATCAGCCTTTIT & CCACCAGTAAAGTCGCAATAAT & -4.1 & & & & 2.1 & 3.5 \\
\hline Ilmg_0349 & fhuD & ferrichrome $A B C$ transporter substrate binding protei & CATTAGGTGCAAATGTTGTTGG & TCAGGATTTGAGCAATCAATT & 5.7 & & & 14.8 & 2.8 & 2.5 \\
\hline Ilmg_2050 & tuf* & translation elongation factor EF-Tu & CACTCCATTCTTCGACAACTACC & AGGCATTACCATTTCAGTTCCTT & & & & & & \\
\hline Ilmg_0102 & $\operatorname{par} A^{*}$ & chromosome partitioning protein parA. & TTCTACAgCCgATtATtGTTCGT & TGGgATtGTTTCTAAtCCAGCTA & & & & & & \\
\hline IImg_0496 & $h \| A^{*}$ & HU-like DNA-binding protein & TTCAATTGATCGGTTTTGGTACT & TCAATGCTTTACCAGCTTTGAAT & & & & & & \\
\hline
\end{tabular}

*tuf, parA and $h l l A$ expressions were used to normalised results.

Fold-changes of differentially expressed genes, in 02 condition in comparison with N2 condition, confirmed using RT-qPCR with a $p$-value $<0.05$ and a |fold-change $>2$ ( $\mathrm{n}=3$ ). Genes parA, tuf and hllA were internal Fold-changes of differentially expressed genes, in $\mathrm{O} 2$ condition in comparison with N2 condition, confirmed using RT-qPCR with a $p$-value $<0.05$ and a |fold-change $>2$ ( $\mathrm{n}=3$ ). Genes parA, tuf and hllA were interna
control genes. 


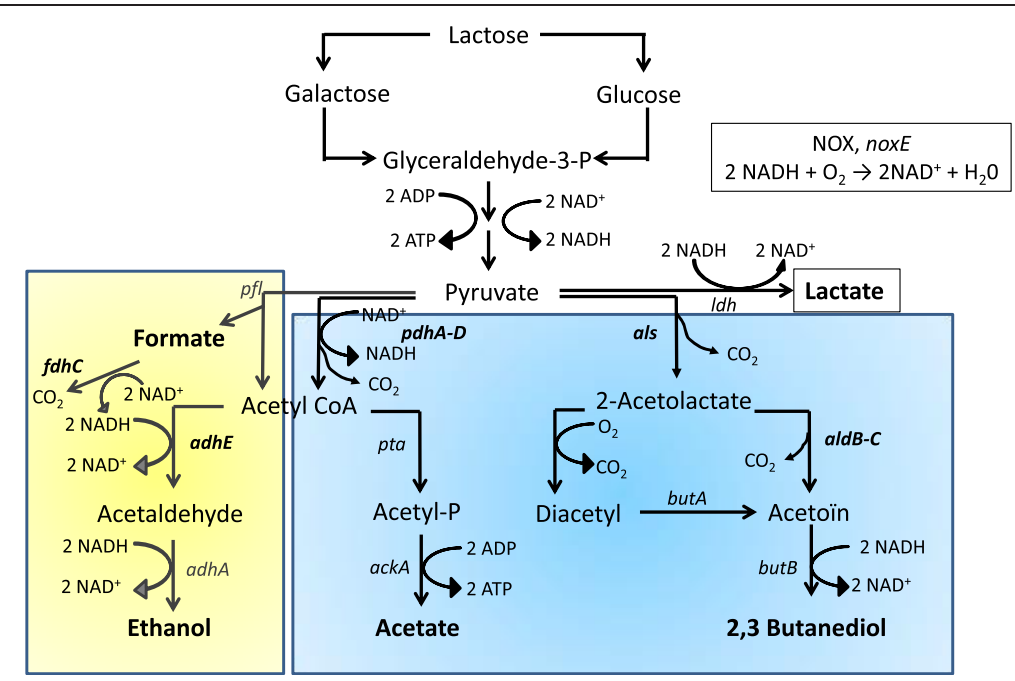

Figure 3 The pyruvate metabolism of Lactococcus lactis. Idh: gene coding for the lactate dehydrogenase; pdhA-D: genes coding for the pyruvate dehydrogenase complex; pfl: gene coding for pyruvate formate-lyase; adhE: gene coding for the acetaldehyde dehydrogenase; adhA: gene coding for the alcohol dehydrogenase; pta: gene coding for the phosphotransacetylase; ackA: gene coding for the acetate kinase, als: gene coding for catabolic and anabolic 2-acetolactate synthase; aldB-C: gene coding for the acetolactate decarboxylase; butA: gene coding for the diacetyl reductase; butB: gene coding for the acetoin reductase; noxE: gene coding for the NADH oxidase (NOX). Adapted from Oliveira et al. [29]. The blue area represents pathways up-regulated in $\mathrm{O} 2$ condition, and the yellow area represents pathways up-regulated in N2 condition.

transporter proteins, respectively. The under-expression of $\operatorname{cad} A$ was confirmed at $1 \mathrm{~h}$ using RT-qPCR, while later, at $5 \mathrm{~h}$ and $8 \mathrm{~h}$, it was found to be over-expressed (Table 2). Genes encoding redox-sensing regulators such as rex and $\operatorname{trm} A$ were also found to be under-expressed under condition O2 (Table 1).

\section{Conjugation was repressed by the presence of dissolved oxygen both at the transcriptomic and phenotypic levels} Nine genes belonging to the L. lactis MG1363 sex-factor [6], a $60 \mathrm{~kb}$ chromosomally located conjugative element capable of high-frequency DNA transfer [30], were underexpressed in condition O2 (Table 1). The adaptive downregulation of these genes by oxygen was most pronounced after $8 \mathrm{~h}$ of growth in agreement with the global adaptation at the transcriptomic level observed in this study. Interestingly, we observed that transfer frequency of the sex-factor was more than 5 times higher under static conditions $\left(25 \pm 2.0 \times 10^{-4}\right.$ transconjugants/donor) than under aerated conditions $\left(4.6 \pm 0.8 \times 10^{-4}\right.$ transconjugants/ donor), thereby confirming that conjugal transfer is increased in limiting oxygen concentrations.

\section{Discussion}

Lactococcus lactis is widely used as a starter in the dairy industry. During cheese-making, it is exposed to oxidative stress, e.g. during stirring, in the early stages of manufacture. L. lactis is known to be tolerant to oxygen. However, the non-respiratory response to oxygen, at the transcriptomic and metabolic levels, has never been described for the early stages of growth. The present results clearly showed that a high initial level of dissolved oxygen in LM17 does not affect the growth of strain MG1363 during the exponential phase, due to an efficient adaptive response at the transcriptional level occurring early in the exponential phase. On the contrary, when the level of dissolved oxygen increased again during the stationary growth phase, the cells suffered a dramatic loss of culturability, while the adaptive response at the transcriptional level was almost absent. This is the first study to simultaneously monitor growth and $\mathrm{pH}$, but also oxygen concentration and redox values, which proved to be important as oxygen concentration varied a lot during growth.

The growth and acidification of L. lactis MG1363 were not affected by oxygen during the exponential growth phase due to efficient oxygen consumption

The same growth and acidification kinetics were displayed under conditions $\mathrm{O} 2$ and N2 during the first hours, proving that strain L. lactis MG1363 has an efficient system to deal with oxygen. It has previously been shown that the presence of dissolved oxygen does not significantly affect growth of L. lactis strains either in LM17 [31], or in milk $[23,32]$. In comparison to anaerobic conditions, the strain MG1363 could grow to an even higher population maximum (10\% of biomass) under microaerobic conditions [33]. Acidification kinetics and final redox values were the same, so oxygen did not affect the main technological abilities of the strain MG1363. However, other properties could have been affected. In contrast, it has been reported that L. lactis subsp. lactis CHCC2862 acidified to a lesser extent under aerated conditions [31]. Furthermore, wild 

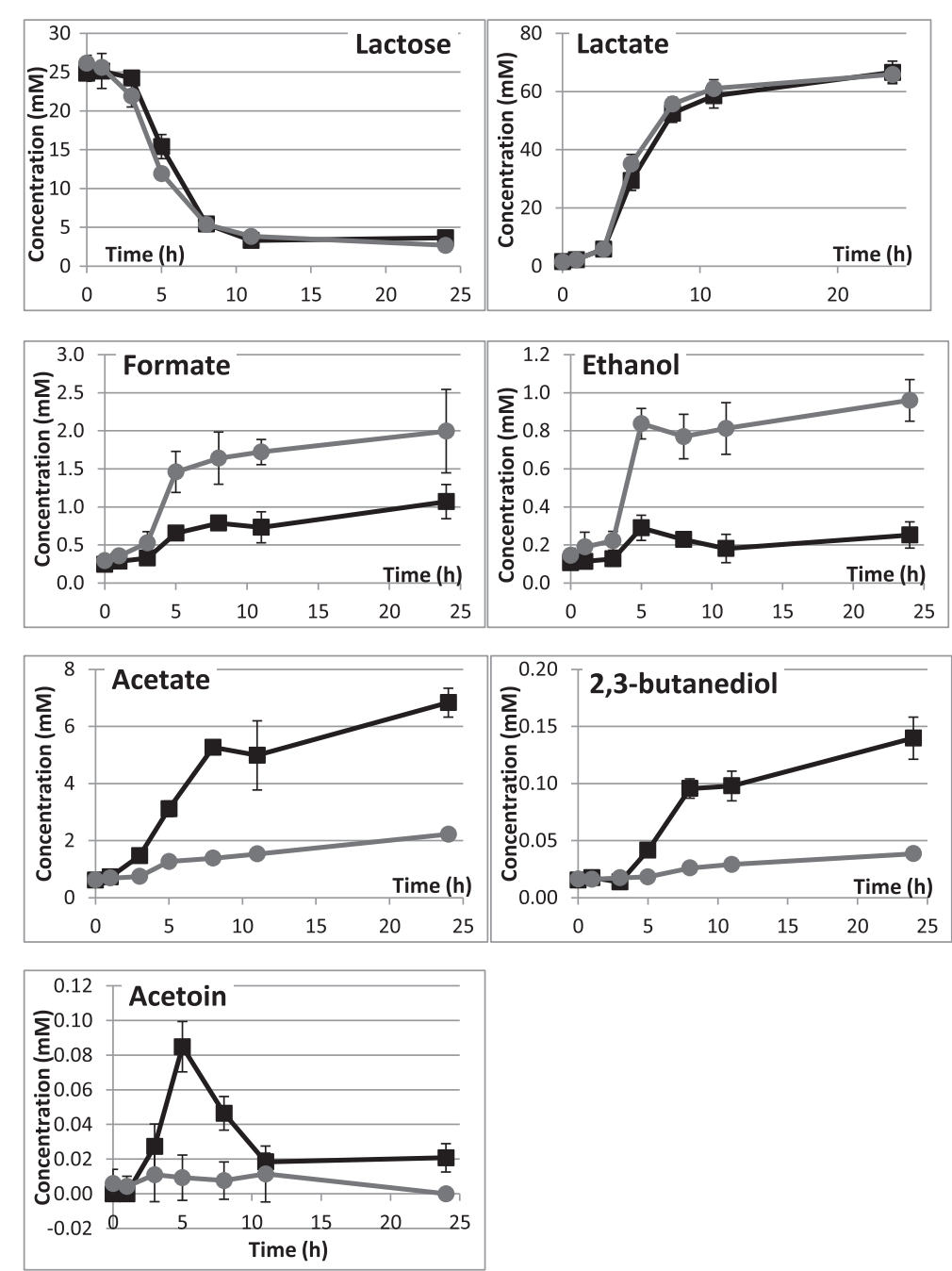

Figure 4 Quantitative analysis by ${ }^{1} \mathrm{H}$ NMR of lactose and metabolites produced by Lactococcus lactis MG1363 in LM17 under 02 condition $(\mathbf{a})$ and under N2 condition $(O)$ over 24 hours of culture at $30^{\circ} \mathrm{C}$. Points are means of concentrations in $\mathrm{mM}(\mathrm{n}=3)$ and bars are standard deviations.

strains of lactococci can reach pH 5.5 in milk with 4-5 hours delay under the condition $\mathrm{O} 2$ in comparison to condition N2 [23]. The resistance to oxygen of the strain MG1363 is most probably due to its efficient oxygen consumption, clearing all oxygen from the media within $4 \mathrm{~h}$. As a result, the redox potential showed a marked decrease. The minimum redox values $\left(E_{h 7}\right)$ reached by strain MG1363 were typical for Lactococcus strains in milk with a minimum value between $-200 \mathrm{mV}$ and $-280 \mathrm{mV}[20,23,24,32]$. Interestingly, these values were also reached under condition $\mathrm{N} 2$, in the absence of dissolved oxygen, giving evidence of a reducing activity independent from the presence of oxygen as previously observed [32]. Reduction of the culture medium by L. lactis MG1363 indeed occurred in two consecutive steps under condition O2: an aerobic reduction with complete oxygen consumption during stage
$\mathrm{A}$ and an anaerobic reduction with a decrease in $\mathrm{E}_{\mathrm{h} 7}$ values after oxygen has disappeared.

\section{L. lactis MG1363 displays multiple resistance systems in response to oxygen at $1 \mathrm{~h}$}

The most important and noticeable adaptation to oxygen was the early over-expression of detoxification and electron transport genes. All these genes code for enzymes protecting cells from damage provoked by reactive oxygen species. Evidence for two independent systems of reduction in L. lactis was shown [32]. The first one is NoxE; it is an oxygen-dependent system, responsible for the majority of oxygen consumption during the exponential phase, but its $\mathrm{pH}$-sensitivity led to its inactivation during the stationary phase when $\mathrm{pH}$ decreased. The second system is oxygen-independent; it is composed of menaquinones 
(vitamin K2) that form part of the electron transport chain (MenC) and NoxAB, both responsible for the anaerobic reduction of the medium after oxygen consumption. However, in the present study, the gene menF (part of MenC system) was over-expressed at $1 \mathrm{~h}$ of culture at the same time as noxE and not later, suggesting that this enzymatic system is also part of the early adaptation to oxygen. These results are in accordance with Pedersen et al. [31], who found that noxE was the most DE gene in aerobic conditions, along with 5 of the men genes. In contrast to the work of Pedersen et al. [31], our results show that the $\operatorname{sod} A$ gene coding for the superoxide dismutase (SOD) was not DE at $1 \mathrm{~h}$. The difference of experimental conditions may partly explain why the gene $\operatorname{sod} A$ was not DE in our conditions. In our conditions, the medium was initially saturated with dissolved oxygen while the medium was constantly aerated in Pedersen et al. [31]; the transcriptomic analysis was performed at OD $=1$ in Pedersen et al. [31] instead of OD $=0.12$ in our study. Furthermore, the strain used for the transcriptomic analysis in Pedersen et al. [31] was not strain MG1363. It has been recently shown that activities of $\mathrm{NADH}$ oxidase and SOD are strain dependent [34].

For the first time, the early over-expression of nucleotide reductase $n r d$ genes of both classes (I and III) is described as a crucial part of the response to oxygen. The genes $n r d D E F G H I$ were all over-expressed. The Nrd family of proteins is responsible for the reduction of ribonucleotide di- and tri-phosphates and thereby provides the building blocks for DNA replication and repair [35]. The NrdEFHI proteins are class I enzymes, which are oxygendependent, while the NrdDG system belongs to the class III enzymes, which can be active under anaerobiosis [36]. Under condition $\mathrm{O} 2$, the most over-expressed operons were $n r d H I$ and $n r d E F$ which is consistent with the fact that they are oxygen-dependent. The ribonucleotide reductase NrdEF uses NrdH as an electron transporter [35]. Surprisingly, the $n r d D G$ operon, which encodes an anaerobic ribonucleotide reductase, was also over-expressed at $1 \mathrm{~h}$, albeit to a lesser extent than the other nrd genes [36].

Another family of genes responsible for the efficient early adaptation to oxygen of strain MG1363 is the reductase and thioreductase family (trxB2, llmg_0276, $m s r A, g s h R$ ) maintaining the intracellular thiol balance [37]. In Bacillus subtilis, two genes, $\operatorname{trx} A$ (thioredoxin) and $\operatorname{tr} x B$ (thioredoxin reductase), are transcriptionally induced under conditions of thiol-specific oxidative stress [38]. In L. lactis, these genes were not found to be over-expressed under aerated conditions at $4 \mathrm{~h}$ of culture by Pedersen et al. [31]. The gshR gene (glutathione reductase) was consistently over-expressed in $\mathrm{O}_{2}$-rich conditions as previously observed. Strain MG1363 is unable to synthetize glutathione but has been shown to display a high glutathione reductase activity on glutathione-rich medium such as LM17 medium [39], which could then protect against oxidative stress. The redox state is regulated by several genes when oxygen is present in the culture. The rex (redox-sensing transcriptional repressor) gene is under-expressed in our study. Rex, widely spread among bacteria [40], notably controls the expression of genes involved in energy metabolism and fermentative growth in several bacteria in response to the intracellular redox potential (NADH/NAD+ ratio). The trmA gene, under-expressed in our conditions, is one of the eight genes of the family of trm genes in MG1363 [6] and a member of the Spx family of proteins [41]. Spx of $B$. subtilis acts as a transcriptional regulator and senses redox conditions. It has been shown that a MG1363 trmA mutant was more resistant to stress with an increased proteolysis capacity [42]. Other genes involved in the electron transport by $\mathrm{Fe}(-\mathrm{S})$-proteins such as nifU and fhuCDG, which code for ferrichrome $A B C$ transporters for heme transport [9], were over-expressed. The fhuCDG genes had not been described as over-expressed under oxidative stress [43] or aerated conditions [31]. Rather our results suggest that these genes, as well as other genes involved in adaptation to oxygen such as $\operatorname{trx} B 2$ (see above), are part of an early and transitory response of L. lactis to oxygen.

Finally, two genes, choQ and choS, coding for transport proteins of the osmoprotectant choline (osmotic stress response), were over-expressed suggesting overlap of stress responses as previously observed [44]. The over-expressed genes llmg_2143, llmg_2144 and llmg_2145 are similar to genes $y m g G, y m g H$ and $y m g I$, respectively encoding two proteins similar to Gls24 family general stress protein and a transmembrane protein that were found to be induced by aerated conditions [31]. It is of interest that llmg 2143 is located next to the integrase of a prophage in MG1363 and the gene environment may differ in other strains.

\section{Lactose fermentation of $L$. lactis MG1363 remains homolactic}

Lactococci essentially produce lactic acid as a main end product [28]. In the present study, the MG1363 strain produced about the same concentration of lactate under the conditions $\mathrm{O} 2$ and N2. However, in agreement with the literature [28], part of the carbon flux or pyruvate flux is directed to mixed-acid fermentation pathway ending with metabolites such as acetate and aroma compounds (acetoin, diacetyl and 2,3-butanediol) under oxidative conditions. As PFL is irreversibly inactivated under aerated conditions [25], the pyruvate pool is deviated to the PDH (pyruvate dehydrogenase complex) and ALS ( $\alpha$-acetolactate synthetase) activities forming acetate and acetolactate, respectively. This pathway increases the ATP yield by acetate production. In parallel to the NADH oxidase activity, L. lactis oxidizes NADH into $\mathrm{NAD}^{+}$with the two enzymes, $\alpha$-acetolactate decarboxylase and 
2.3-butanediol dehydrogenase, responsible for acetoin reduction into 2.3-butanediol [45]. The metabolic shift observed is likely a result of the under-expression of frdC and $a d h E$ and the over-expression of $p d h A B D$, als and ald $C$ genes. However, the production of these metabolites was observable two hours after the observed shift at the gene expression level. Interestingly, Pedersen et al. [31] did not mention the over-expression of these genes, suggesting this could be part of the very early adaptation of L. lactis to oxygen as mentioned above.

\section{L. lactis MG1363 adaption to oxygen disappeared in the stationary phase}

In stages $\mathrm{C}$ and $\mathrm{D}$, in condition $\mathrm{O} 2$ only, the oxygen concentration increased again to up to $50 \%$ of the initial value. Instead of a novel adaptation, we observed a drastic loss of culturability of the MG1363 cells. On one hand, such a loss of culturability does not exist in milk [23], not even for the MG1363 strain grown under the same conditions in milk (unpublished results). On the other hand, growth in M17 is most often monitored as OD and not colony forming unit enumerations [8,12,31,37]. Consequently, to our knowledge, this drastic loss of culturability of L. lactis cells has not been reported before. Other strains of L. lactis (spp. lactis IL1403, spp. cremoris ML3 and SK11, both with a full plasmid complement) exhibited a loss of culturability after carbon exhaustion in M17 medium [46]. Strains MG1363 and ML3 (NCDO 763) are closely related and differ with regards to their chromosomal topography due to different chromosomal inversions [6]. In our study, carbon consumption stopped at very low concentrations $(3 \mathrm{mM})$ but starvation was not observed during stage D under either condition. The loss of culturability observed in the present study may thus be due to oxidative stress only in combination with acid stress, and carbon source limitation might be a contributing factor. In milk, the loss of culturability does not occur because the increase of oxygen is extremely limited during the stationary growth phase and the lactose concentration was still high [23,32].

\section{Surprisingly, conjugation is repressed in the presence of oxygen}

The sex factor of the strain MG1363 contains 59 putative genes [6], 10 of which are predicted to encode proteins that are evolutionary conserved between 5 ancestrally related Gram-positive coccal conjugation systems [47] and are suggested to be part of a minimal set of genes required for conjugation. Among those genes, orf 24 and orf 28 were found to be under-expressed under conditions $\mathrm{O} 2$ at time point $8 \mathrm{~h}$. We anticipated that in the presence of oxygen, a reduction of their expression and possibly of the other 7 genes would translate into a reduction of the sex-factor transfer efficiency. We show here that conjugal transfer is indeed increased 5-fold in limiting oxygen concentrations. These results are the first to describe the repression of the sex-factor conjugation under aerated conditions. This surprising result is in conflict with the common belief that conjugation facilitates adaptability of the cells to environmental stress [48].

\section{Conclusion}

This study is the first aiming to investigate adaptation to oxygen by combining phenotypic (growth/acidification/ conjugation), transcriptomic and metabolomic analyses over a $24 \mathrm{~h}$-period of culture. It is very interesting to observe how uncorrelated the results of these different analyses could be. While no differences were visible at the phenotypic level during the exponential phase (same growth/acidification profiles independently of the aeration conditions), major differences occurred at the transcriptomic level, revealing a strong adaptation of L. lactis to the oxygen present. On the contrary, while transcriptomic profiles did not reveal major difference between conditions $\mathrm{O} 2$ and N2 in stationary phase, a strong loss of culturability was observed under oxygenated conditions. The present results were obtained for a lac ${ }^{+} / \mathrm{prt}^{+}$strain directly derived from the strain MG1363. While strain MG1363 is regarded as a model organism representative of Lactococcus lactis, its behavior may not truly mirror that of an industrially used cheese starter culture. In all cheese-making processes, the milk is stirred during the first stages of the process, so oxygen is present early rather than later on. It is thus important to report that strains of the most used starter, L. lactis, are able to adapt to the presence of oxygen early in the exponential growth phase, when oxidative stress is most likely to occur. It is of major importance to understand how key technological abilities such as acidification and reduction of the medium are preserved in the presence of early oxidative stress.

\section{Methods}

\section{Strains and culture conditions}

The strain of Lactococcus lactis subsp. cremoris MG1363 [49] carrying the pLP712 plasmid (from the Institute of Food Research collection, Norwich, UK) was used for all fermentations. The plasmid pLP712 carries the protease gene and the lac operon [50] and allows the strain to growth on a medium containing lactose. A $-80^{\circ} \mathrm{C}$ vial of the strain was cultivated in M17 liquid medium supplemented with $0.5 \%$ lactose and incubated at $30^{\circ} \mathrm{C}$. After two successive cultures, the strain was grown overnight in $100 \mathrm{ml}$ of the same broth medium. This overnight culture was used to inoculate the fermenters at $1 \%(\mathrm{v} / \mathrm{v})$.

\section{Fermentation conditions}

All fermentations were performed in one set of 2 1-bioreactors (LH Fermentation, series 2000) each with its own 
monitoring system. Fermentations were performed in filtered LM17 (M17 medium with $0.5 \%$ of lactose added). Before fermentation, the filtered LM17 was poured in the fermenters and gas conditions were set up before inoculation. For condition $\mathrm{O} 2$, pure $\mathrm{O}_{2}$ (Air Liquide) was sparged in the bioreactor until complete saturation with dissolved oxygen was reached. For condition N2, the bioreactor was sparged with pure $\mathrm{N}_{2}$ (Air Liquide) until no dissolved oxygen could be detected. Gas sparging was then stopped and inoculation was performed in both bioreactors. Fermentation protocols were carried out independently three times in LM17. The redox potential, the dissolved oxygen level and the $\mathrm{pH}$ were online monitored during 24 hours. All the sensors were autoclaved in the fermenters prior to fermentations. Dissolved oxygen concentration in the growth medium was measured using a polarographic electrode (Ingold). The $\mathrm{pH}$ and redox potential were monitored using autoclavable gel-filled electrodes (Mettler-Toledo). All electrodes were connected to an online meter ( $\mathrm{LH}$ Fermentation, series 2000) that recorded the $\mathrm{pH}$, dissolved oxygen and redox values every minute for $24 \mathrm{~h}$. Growth was followed by measuring both the $\mathrm{OD}_{600}$ every hour until $11 \mathrm{~h}$ and at $24 \mathrm{~h}$, and the cultivable counts every two hours until $10 \mathrm{~h}$ and $24 \mathrm{~h}$, using a spiral platter on $\mathrm{M} 17+1 \%$ lactose plates. Sampling for nuclear magnetic resonance (NMR) spectroscopy was performed at the same time than sampling for $\mathrm{OD}_{600}$ for growth and samples taken were stored at $-80^{\circ} \mathrm{C}$ until NMR analysis.

The redox potential is the value measured from equilibrium of the redox couples in the medium. The measured value $\left(E_{m}\right)$ had to be corrected according to (i) the reference electrode and the temperature giving $\mathrm{E}_{\mathrm{h}}$ (ii) the $\mathrm{pH}$ giving $\mathrm{E}_{\mathrm{h} 7}$. The electrodes have been treated and the calculation made as described in Abraham et al. [20].

\section{Quantitative analysis by nuclear magnetic resonance ( ${ }^{1} \mathrm{H}$ NMR)}

NMR was used to identify the presence, absence and concentration of several metabolites in growth medium. The supernatant samples were thawed at room temperature and prepared for ${ }^{1} \mathrm{H}$ NMR spectroscopy by mixing $550 \mu \mathrm{l}$ of spent medium with $200 \mu \mathrm{l}$ phosphate buffer $(0.2 \mathrm{M}$ $\mathrm{K}_{2} \mathrm{HPO}_{4}$ and $0.038 \mathrm{M} \mathrm{KH}_{2} \mathrm{PO}_{4}, \mathrm{pH}$ 7.4) made up in $100 \%$ $\mathrm{D}_{2} \mathrm{O}$ and containing $0.06 \%$ sodium azide, and $1 \mathrm{mM}$ TSP (sodium 3-(Trimethylsilyl)-propionate-d4) as a chemical shift reference. The sample was mixed and $500 \mu \mathrm{l}$ transferred into a $5 \mathrm{~mm}$ NMR tube for spectral acquisition. ${ }^{1} \mathrm{H}$ NMR spectra were recorded at $600 \mathrm{MHz}$ on a Bruker Avance spectrometer (Bruker BioSpin $\mathrm{GmbH}$ ) running TOPSPIN 2.0 software and fitted with a cryoprobe and a 60 slot auto-sampler. $\mathrm{D}_{2} \mathrm{O}$ was used as the internal lock. Each spectrum consisted of 64 scans of 32768 complex data points with a spectral width of $8389 \mathrm{~Hz}(14 \mathrm{ppm})$.
The nuclear Overhauser effect spectroscopy (NOESY) pre-saturation experiment was used for each sample using a low power irradiation at the water frequency during the recycle delay to suppress the massive water signal. Spectra were Fourier transformed with $0.3 \mathrm{~Hz}$ line broadening, automatically phased and manually baseline corrected using the TOPSPIN software. The concentrations of metabolites were measured by a previously validated NMR targeted profiling method [51]. Spectra referenced to TSP (0 ppm) were uploaded in the Chenomx NMR suite version 6.0 software (Chenomx Inc.) and compounds identified and quantified by fitting library reference spectra of individual metabolites to the experimental spectrum.

\section{RNA and DNA extraction}

Volumes of culture for RNA extraction were adapted to the concentration of cells (from 1.5 to $60 \mathrm{ml}$ ) in order to reach at least $10^{9}$ cells in total. Samples for RNA extraction were harvested directly in chilled phenol/ethanol $(10 \% / 90 \%)$ solution for a final concentration of $2 \%(\mathrm{v} / \mathrm{v})$ of phenol in order to stop the transcriptomic activity. After incubation in ice-water for $30 \mathrm{~min}$, the mixture was diluted 1:5 with a solution of citrate (1.8\%) in water $98 \%$ / phenol 2\%. All the samples were then centrifuged at $12,000 \mathrm{~g}$ for $15 \mathrm{~min}$ at $4^{\circ} \mathrm{C}$, the cells were washed in $2 \mathrm{ml}$ of the citrate water/phenol $2 \%$ solution, and centrifuged at $10,000 \mathrm{~g}$ for $20 \mathrm{~min}$ at room temperature. The cell pellets were then frozen at $-80^{\circ} \mathrm{C}$ until RNA extraction.

Pellets were thawed at room temperature, and washed twice in $1 \mathrm{ml}$ of TE buffer $(10 \mathrm{mM}$ Tris- $\mathrm{HCl}$ containing $1 \mathrm{mM}$ EDTA $\bullet \mathrm{Na}_{2}, \mathrm{pH} 8.0$ (Sigma)). Total RNA was then extracted using the SV Total RNA isolation kits (Promega) according to the manufacturer's protocol, except that cells were lysed using $100 \mu \mathrm{l} /$ sample of a lysis buffer $\left(1 \mathrm{ml}\right.$ of TE buffer $+20 \mathrm{mg} \mathrm{ml}^{-1}$ of lysozyme +10 unit $\mathrm{ml}^{-1}$ of mutanolysin) and incubated at $37^{\circ} \mathrm{C}$ for 30 minutes. The RNA quantity was checked using $1 \mu 1$ of the sample in a Nanodrop 1000 apparatus (Nanodrop) and RNA quality was checked using the RNA 6000 Nano kit on a Bioanalyser 2100 (Agilent Technologies). Highquality total RNAs (two sharp peaks for $16 \mathrm{~S}$ and $23 \mathrm{~S}$ ribosomal RNAs) were obtained for all the samples.

gDNA of L. lactis MG1363 was prepared from a $20 \mathrm{ml}$ sample at an $\mathrm{OD}_{600}$ of 1 of a culture grown under static conditions on M17 supplemented with $1 \%$ lactose at $30^{\circ} \mathrm{C}$. gDNA was extracted following instructions of Qiagen Genomic tip kit (Qiagen).

\section{Genomic expression analysis}

Home-made microarrays containing 2459 PCR amplicon probes representing the coding sequences of the genome of L. lactis MG1363 were designed. Probes coding sequences from the lactococcal plasmid pLP712 were added 
[50]. The array design is available on the Arrayexpress database under the accession number A-MEXP-2216.

Ten $\mu \mathrm{g}$ of total RNA were labeled overnight at $42^{\circ} \mathrm{C}$ using $2 \mu \mathrm{l}$ of Cy5-dCTP (Amersham Pharmacia), $4 \mu \mathrm{l}$ of reverse transcriptase (AffinityScript, StrataGene) and $5 \mu \mathrm{g}$ of random hexamers (Bioprime DNA labeling System, Invitrogen). Labeled cDNA was purified using QIA-Quick PCR purification kit (Quiagen) and eluted in $50 \mu \mathrm{l}$ of RNAse-free water. For each microarray sample, $0.3 \mu \mathrm{g}$ of gDNA were labeled with Cy3-dCTP using the same protocol. The expression profile of L. lactis MG1363 was determined by hybridizing Cy5-labeled cDNA corresponding to each sample of RNA with Cy3-labeled gDNA. Genomic DNA was used as a reference for normalization. At all the time points, microarray analysis was performed in triplicate (using independent biological samples).

For each time point, microarrays were hybridized overnight at $63^{\circ} \mathrm{C}$ with both labeled cDNA at a defined time point and labeled genomic DNA. Slides were then washed twice for $5 \mathrm{~min}$ in each of the following solutions: 2X SSC (where 1X SSC is $0.15 \mathrm{M} \mathrm{NaCl} / 0.015 \mathrm{M}$ sodium citrate) heated at $63^{\circ} \mathrm{C}, 1 \mathrm{X} \mathrm{SSC}$ at room temperature and $0.2 \mathrm{X}$ SSC at room temperature. The slides were dried by centrifugation (1200 rpm, $5 \mathrm{~min}$, room temperature) and scanned on a GenePix 4000A scanner (Axon Instruments). The fluorescent intensities for each cDNA/gDNA spot were measured using GenePix Pro 3.0 software (Axon Instruments).

\section{Statistical analysis}

Median intensity of each spot was used as signal. To determine the expression profiles of L. lactis MG1363 under condition $\mathrm{O} 2$ and condition $\mathrm{N} 2$, data were analyzed with the $\mathrm{R}$ software [52]. Oligonucleotides with a very low signal for gDNA (corresponding to Signal Noise Ratio SNR - lower than 2 in more than $75 \%$ of microarrays) were flagged and removed from further analysis. Data were first normalized per spot (cDNA signals divided by corresponding gDNA signals), $\log _{2}$-transformed and then normalized per chip. Statistical analysis was performed using the ANOVA test considering a p-value and FDR lower than 0.05 . Genes showing significant change in expression during fermentation with or without oxygen feed and a $\leq 0.5$ - or $\geq 2$-fold change were considered as being differentially expressed.

Metabolomic data with growth/pH kinetics have been analyzed using a repeated series ANOVA (library nlme) in software R [52]. Models taking time and conditions $(\mathrm{O} 2$ and $\mathrm{N} 2)$ as factors were tested. Time was introduced as a quantitative factor at degree-1 polynomial equation for the model. The results give the significance for each factor and their interaction (condition, time, time:condition). In this study, we focused on the significance of condition effect over the 24 h-time-course.

\section{Quantitative real time PCR (RT-qPCR)}

In order to confirm transcriptomic analyses, quantitative RT-PCR experiments were carried out. Non-contamination of RNA sample by gDNA was confirmed by qPCR prior to cDNA synthesis. cDNA was synthesized using the highcapacity cDNA archive kit (Applied Biosystems) as recommended by the manufacturer. Quantitative real-time PCR was performed using an Opticon 2 real time PCR detector (BIORAD). The mixture contained power SYBR Green PCR master Mix (1X) (Applied Biosystems), each primer $(0.5 \mu \mathrm{M})$ (sequences are in Table 2) and cDNA template. Thermal cycling consisted of $10 \mathrm{~min}$ at $95^{\circ} \mathrm{C}$, followed by 40 cycles of $15 \mathrm{~s}$ at $95^{\circ} \mathrm{C}$ and $60 \mathrm{~s}$ at $60^{\circ} \mathrm{C}$. A melting curve analysis $\left(60^{\circ} \mathrm{C}\right.$ to $\left.99^{\circ} \mathrm{C}\right)$ was performed after the thermal profile to ensure specificity and PCR efficiency was calculated from the log-linear portion of the standard curves and comprise between $85 \%$ and $105 \%$ for every RT-qPCR run. Quantitative RT-PCR for all experimental time points was performed in triplicate (independent biological triplicates). Standard curves were generated to calculate the copy number of each gene in each sample. The most stable control genes were determined by geNorm among five potential genes. Real-time quantitative PCR data were normalized by geometric averaging of three internal control genes (parA, tuf and hllA). Gene expression was thus expressed as relative expression with regard to the normalization factor calculated by geNorm. Statistical analysis was performed using ANOVA test considering a p-value lower than 0.05 to identify genes showing significant change in expression with time.

\section{Conjugation as transconjugant frequency}

To measure the sex factor transfer efficiency, the method described for plasmid transfer measurement in Enterococcus faecalis [53] and adapted by Stentz et al. [54] was used. Briefly, donor (strain FI8164) and recipient (strain FI9012) strains (from Institute of Food Research, Norwich, $\mathrm{UK})$ were grown on $\mathrm{M} 17$ glucose $0.5 \%(\mathrm{v} / \mathrm{v})$ at $30^{\circ} \mathrm{C}$ with tetracycline and rifampicin, respectively. Overnight cultures of both strains were diluted 100 times in fresh GM17 without antibiotic. After $4 \mathrm{~h}$ of growth, under both static (no agitation and limited head-space with $20 \mathrm{ml}$ ) and agitated (agitation $200 \mathrm{rpm}$ and important headspace with $20 \mathrm{ml}$ ) for the donor strain and static conditions for the recipient, donor and recipient strains were mixed at a ratio 1:10. The mixture was vortexed for $30 \mathrm{~s}$, centrifuged at $5000 \mathrm{~g}$ for $5 \mathrm{~min}$ in order to optimize donor-recipient mating, and left 1 hour at $30^{\circ} \mathrm{C}$. Serial dilutions were made in PBS and plated on GM17 agar containing rifampicin (recipient and transconjugant selection), tetracycline (donor and transconjugant selection), and rifampicin and tetracycline (transconjugant selection). Transfer frequencies were calculated as transconjugants per donor. 


\section{Additional file}

Additional file 1: Table S1. Fold-changes of differentially expressed genes of the strain MG1363, from a whole-genome microarray analysis, in $\mathrm{O} 2$ condition in comparison with N2 condition. Genes were significantly ( $p$-value $<0.5)$ differentially expressed with a FDR $<0.5$ and a |fold-change $\mid>2$.

\section{Competing interests}

The authors declare that they have no competing interests.

\section{Authors' contributions}

MC performed the statistical analysis of the microarray data, took part to draft the manuscript GLG performed the NMR spectrometry analyses UW helped with the microarray experiments and improved the manuscript SE significantly helped to draft the manuscript and to the interpretation of the data CS helped to conceive the study and to the coordination RS designed and performed the conjugation experiments and helped to draft the manuscript SJ conceived the study (fellow of the EU grant) performed the microarray experiments, draft the manuscript. All authors read and approved the final manuscript.

\section{Acknowledgements}

This work has been supported by the European Union with a Marie Curie Intra-European Fellowship (Project number: 41161, acronym: OXYRED). The authors are grateful to Pascal Pachot, Stat-Plan, (http://pachot.wix.com/stat-plan) for statistical analysis of the NMR spectrometry and kinetics data. The authors would like to thank Hélène Falentin for improving the manuscript and to Alyson Yee for correcting the English.

\section{Author details}

${ }^{1}$ Institute of Food Research, Norwich Research Park, Colney, Norwich NR4 7UA, UK. ${ }^{2}$ INRA, UMR1253, F-35000 Rennes, France. ${ }^{3}$ AGROCAMPUS OUEST, UMR1253, F-35000 Rennes, France. ${ }^{4}$ Present address: Research Unit Aliments Bioprocédés Toxicologie Environnements (UR ABTE) E.A. 4651, Université de Caen Basse-Normandie, Esplanade de la paix, 14032 CAEN cedex, France. ${ }^{5}$ Present address: 15 Albury Walk, Eaton, Norwich NR4 6JE, UK. ${ }^{6} 65$ Rue de Saint-Brieuc, 35042 Rennes cedex, France.

Received: 22 January 2014 Accepted: 18 November 2014 Published: 3 December 2014

\section{References}

1. Klaenhammer T, Altermann E, Arigoni F, Bolotin A, Breidt F, Broadbent JR, Cano R, Chaillou S, Deutscher J, Gasson MJ, Van de Guchte M, Guzzo J, Hartke A, Hawkins T, Hols P, Hutkins RW, Kleerebezem M, Kok J, Kuipers OP, Lubbers M, Maguin E, McKay L, Mills D, Nauta A, Overbeek R, Pel H, Pridmore D, Saier M, Van Sinderen D, Sorokin A, et al: Discovering lactic acid bacteria by genomics. Antonie Van Leeuwenhoek 2002, 82:29-58.

2. Cocaign-Bousquet $M$, Even $S$, Lindley $N$, Loubière P: Anaerobic sugar catabolism in Lactococcus lactis: genetic regulation and enzyme control over pathway flux. Appl Microbiol Biotechnol 2002, 60:24-32.

3. Flahaut N, Wiersma A, Bunt B, Martens D, Schaap P, Sijtsma L, Santos V, Vos W: Genome-scale metabolic model for Lactococcus lactis MG1363 and its application to the analysis of flavor formation. Appl Microbiol Biotechnol 2013, 97:8729-8739.

4. Schleifer KH, Kraus J, Dvorak C, Kilpper-Balz R, Collins MD, Fischer W: Transfer of Streptococcus lactis and related Streptococci to the Genus Lactoccoccus gen. nov. Syst Appl Microbiol 1985, 6:183-195.

5. Bolotin A, Wincker P, Mauger S, Jaillon O, Malarme K, Weissenbach J, Ehrlich SD, Sorokin A: The complete genome sequence of the lactioc acid bacterium Lactococcus lactis ssp. lactis IL1403. Genome Res 2001, 11:731-753.

6. Wegmann U, O'Connell-Motherway M, Zomer A, Buist G, Shearman C, Canchaya C, Ventura M, Goesmann A, Gasson MJ, Kuipers OP, van Sinderen D, Kok J: Complete genome sequence of the prototype lactic acid bacterium Lactococcus lactis subsp. cremoris MG1363. J Bacteriol 2007, 189:3256-3270.

7. Linares DM, Kok J, Poolman B: Genome sequences of Lactococcus lactis MG1363 (revised) and NZ9000 and comparative physiological studies. J Bacteriol 2010, 192:5806-5812.
8. Duwat $P$, Sourice $S$, Cesselin B, Lamberet G, Vido K, Gaudu P, Le Loir $Y$, Violet $F$, Loubière $P$, Gruss A: Respiration capacity of the fermenting bacterium Lactococcus lactis and its positive effects on growth and survival. J Bacterio/ 2001, 183:4509-4516.

9. Gaudu P, Vido K, Cesselin B, Kulakauskas S, Tremblay J, Rezaïki L, Lamberet G, Sourice S, Duwat P, Gruss A: Respiration capacity and consequences in Lactococcus lactis. Antonie Van Leeuwenhoek 2002, 82:263-269.

10. Rezaiki L, Cesselin B, Yamamoto Y, Vido K, Van West E, Gaudu P, Gruss A: Respiration metabolism reduces oxidative and acid stress to improve long-term survival of Lactococcus lactis. Mol Microbiol 2004, 53:1331-1342.

11. Neves AR, Ramos A, Costa H, van Swam II, Hugenholtz J, Kleerebezem M, de Vos W, Santos H: Effect of different NADH oxidase levels on glucose metabolism by Lactococcus lactis: Kinetics of intracellular metabolite pools determined by In Vivo nuclear magnetic resonance. Appl Environ Microbiol 2002, 68:6332-6342.

12. Zomer AL, Buist G, Larsen R, Kok J, Kuipers OP: Time-resolved determination of the CcpA Regulon of Lactococcus lactis subsp. cremoris MG1363. J Bacteriol 2007, 189:1366-1381.

13. Carvalho AL, Turner DL, Fonseca LL, Solopova A, Catarino T, Kuipers OP, Eberhard OV, Neves AR, Santos H: Metabolic and transcriptional analysis of acid stress in Lactococcus lactis, with a focus on the kinetics of lactic acid pools. PLOS ONE 2013, 8:e68470.

14. de Jong A, Hansen ME, Kuipers OP, Kilstrup M, Kok J: The transcriptional and gene regulatory network of Lactococcus lactis MG1363 during growth in milk. PLOS ONE 2013, 8:e53085.

15. Cretenet $M$, Laroute $V$, Ulve $V$, Jeanson $S$, Nouaille $S$, Even $S$, Piot M, Girbal L, Le Loir Y, Loubiere P, Lortal S, Cocaign-Bousquet M: Dynamic analysis of the Lactococcus lactis transcriptome in cheeses made from milk concentrated by ultrafiltration reveals multiple strategies of adaptation to stresses. Appl Environ Microbiol 2011, 77:247-257.

16. Dressaire $C$, Redon $E$, Milhem $H$, Besse $P$, Loubiere $P$, Cocaign-Bousquet $M$ : Growth rate regulated genes and their wide involvement in the Lactococcus lactis stress responses. BMC Genomics 2008, 9:343.

17. Raynaud S, Perrin R, Cocaign-Bousquet M, Loubiere P: Metabolic and transcriptomic adaptation of Lactococcus lactis subsp. lactis biovar diacetylactis in response to autoacidification and temperature downshift in skim milk. Appl Environ Microbiol 2005, 71:8016-8023.

18. Redon $E$, Loubiere $P$, Cocaign-Bousquet M: Transcriptome analysis of the progressive adaptation of Lactococcus lactis to carbon starvation. J Bacteriol 2005, 187:3589-3592.

19. Xie Y, Chou L, Cutler A, Weimer B: DNA macroarray profiling of Lactococcus lactis subsp. lactis IL1403 gene expression during environmental stresses. Appl Environ Microbiol 2004, 70:6738-6747.

20. Abraham S, Cachon R, Jeanson S, Ebel B, Michelon D, Aubert C, Rojas C, Feron $G$, Beuvier E, Gervais P, De Conink J: A procedure for reproducible measurement of redox potential (Eh) in dairy processes. Dairy Sci Technol 2013, 93:1-16.

21. Tengerdy R: Redox potential changes in 2-keto-L-gulonic acid fermentation. I-Correlation betweenredox potential and dissolved oxygen concentration. J Biotechnol Microbiol Technol Eng 1961, 3:241-253.

22. Aubert C, Capelle N, Jeanson S, Eckert H, Diviès C, Cachon R: Le potentiel d'oxydoréduction et sa prise en compte dans les procédés d'utilisation des bactéries lactiques. Sci Aliments 2002, 22:177-187.

23. Jeanson S, Hilgert N, Coquillard MO, Seukpanya C, Faiveley M, Neveu P, Abraham C, Georgescu V, Fourcassié P, Beuvier E: Milk acidification by Lactococcus lactis is improved by decreasing the level of dissolved oxygen rather than decreasing redox potential in the milk prior to inoculation. Int J Food Microbiol 2009, 131:75-81.

24. Cachon $R$, Jeanson $S$, Aldarf $M$, Diviès $C$ : Characterization of lactic starters based on acidification and reduction activities. Lait 2002, 82:281-288.

25. Cesselin B, Derré-Bobillot A, Fernanadez A, Lamberet G, Lechardeur D, Yamamoto Y, Pedersen MB, Garrigues C, Gruss A, Gaudu P: Responses of Lactic Acid Bacteria to Oxidative Stress. In Stress Responses of Lactic Acid Bacteria. Food Microbiology and Food Safety edition. Edited by Tsakalidou E, Papadimitriou K. Springer Science; 2011:111-127.

26. Duwat $P$, Cesselin B, Sourice S, Gruss A: Lactococcus lactis, a bacterial model for stress responses and survival. Int J Food Microbiol 2000, 55:83-86.

27. Miyoshi A, Rochat T, Gratadoux J-J, LeLoir Y, Costa Oliveira S, Langella P, Azevedo V: Oxidative stress in Lactococcus lactis. Genet Mol Res 2003, 2:348-359. 
28. Neves AR, Pool WA, Kok J, Kuipers OP, Santos H: Overview on sugar metabolism and its control in Lactococcus lactis - the input from in vivo NMR. FEMS Microbiol Rev 2005, 29:531-554.

29. Oliveira A, Nielsen J, Forster J: Modeling Lactococcus lactis using a genome-scale flux model. BMC Microbiol 2005, 5:39.

30. Gasson MJ, Godon JJ, Pillidge CJ, Eaton TJ, Jury K, Shearman CA Characterization and exploitation of conjugation in Lactococcus lactis. Int Dairy J 1995, 5:757-762.

31. Pedersen MB, Garrigues C, Tuphile K, Brun C, Vido K, Bennedsen M, Møllgaard H, Gaudu P, Gruss A: Impact of Aeration and Heme-activated respiration on Lactococcus lactis gene expression: identification of a heme-responsive operon. J Bacteriol 2008, 190:4903-4911.

32. Tachon S, Brandsma JB, Yvon M: NoxE NADH oxidase and the electron transport chain are responsible for the ability of Lactococcus lactis to decrease the redox potential of milk. Appl Environ Microbiol 2010, 76:1311-1319.

33. Jensen NBS, Melchiorsen CR, Jokumsen KV, Villadsen J: Metabolic behavior of Lactococcus lactis MG1363 in microaerobic continuous cultivation at a low dilution rate. Appl Environ Microbiol 2001, 67:2677-2682.

34. Kimoto-Nira H, Moriya N, Ohmori H, Suzuki C: Altered superoxide dismutase activity by carbohydrate utilization in a Lactococcus lactis strain. J Food Protect 2014, 77:1161-1167.

35. Jordan A, Pontis E, Aslund F, Hellman U, Gibert I, Reichard P: The ribonuclease reductase system of Lactococcus lactis. J Chem Biol 1996, 271:8779-8785.

36. Torrents E, Eliasson R, Wolpher H, Graslund A, Reichard P: The anaerobic ribonucleotide reductase from Lactococcus lactis. J Chem Biol 2001, 276:33488-33494.

37. Vido K, Diemer H, Van Dorsselaer A, Leize E, Juillard V, Gruss A, Gaudu P. Roles of thioredoxin reductase during the aerobic life of Lactococcus lactis. J Bacteriol 2005, 187:601-610.

38. Nakano S, Küster-Schöck E, Grossman AD, Zuber P: Spx-dependent global transcriptional control is induced by thiol-specific oxidative stress in Bacillus subtilis. Proc Natl Acad Sci U S A 2003, 100:13603-13608.

39. Li Y, Hugenholtz J, Abee T, Molenaar D: Glutathione protects Lactococcus lactis against oxidative stress. Appl Environ Microbiol 2003, 69:5739-5745.

40. Ravcheev DA, Li X, Latif H, Zengler K, Leyn SA, Korostelev YD, Kazakov AE, Novichkov PS, Osterman AL, Rodionov DA: Transcriptional regulation of central carbon and energy metabolism in bacteria by redox-responsive repressor rex. J Bacterio/ 2012, 194:1145-1157.

41. Turner MS, Tan YP, Giffard PM: Inactivation of an iron transporter in Lactococcus lactis results in resistance to tellurite and oxidative stress. Appl Environ Microbiol 2007, 73:6144-6149.

42. Frees $D$, Varmanen $\mathrm{P}$, Ingmer $\mathrm{H}$ : Inactivation of a gene that is highly conserved in Gram-positive bacteria stimulates degradation of non-native proteins and concomitantly increases stress tolerance in Lactococcus lactis. Mol Microbiol 2001, 41:93-103.

43. Smith WM, Dykes GA, Soomro AH, Turner MS: Molecular Mechanisms of Stress Resistance in Lactococcus Lactis. In Topics in Applied Microbiology and Microbial Biotechnology. Edited by Mendez-Vilas A. Badajoz, Spain: Formatex Reasearch Center; 2010:1106-1118.

44. Rallu F, Gruss A, Maguin E: Lactococcus lactis and stress. Antonie Van Leeuwenhoek 1996, 70:243-251.

45. Cocaign-Bousquet M, Garrigues C, Loubiere P, Lindley ND: Physiology of pyruvate metabolism in Lactococcus lactis. Antonie Van Leeuwenhoek 1996, 70:253-267

46. Ganesan B, Stuart MR, Weimer BC: Carbohydrate starvation causes a metabolically active but nonculturable state in Lactococcus lactis. Appl Environ Microbiol 2007, 73:2498-2512.

47. Stentz R, Wegmann U, Parker M, Bongaerts R, Lesaint L, Gasson M, Shearman C: CsiA is a bacterial cell wall synthesis inhibitor contributing to DNA translocation through the cell envelope. Mol Microbiol 2009, 72:779-794.

48. Aminov Rl: Horizontal gene exchange in environmental microbiota. Front Microbiol 2011, 2:158.

49. Gasson MJ: Plasmid complements of Streptococcus lactis NCDO 712 and other lactic streptococci after protoplast-induced curing. J Bacterio/ 1983, 154:1-9.

50. Wegmann U, Overweg K, Jeanson S, Gasson M, Shearman C: Molecular characterisation and structural instability of the industrially important composite metabolic plasmid pLP712. Microbiology 2012, 158:2936-2945.
51. Weljie AM, Newton J, Mercier P, Carlson E, Slupsky CM: Targeted profiling: quantitative analysis of ${ }^{1} \mathrm{H}$ NMR metabolomics data. Anal Chem 2006, 78:4430-4442.

52. R Development Core Team: R: A Langage and Environment for Statistical Computing. Vienna, Austria: R Fondation for Statistical Computing; 2008.

53. Waters CM, Dunny GM: Analysis of functional domains of the Enterococcus faecalis pheromone-induced surface protein aggregation substance. J Bacteriol 2001, 183:5659-5667.

54. Stentz R, Jury K, Eaton T, Parker M, Narbad A, Gasson M, Shearman C: Controlled expression of CluA in Lactococcus lactis and its role in conjugation. Microbiology 2004, 150:2503-2512.

doi:10.1186/1471-2164-15-1054

Cite this article as: Cretenet et al:: Early adaptation to oxygen is key to the industrially important traits of Lactococcus lactis ssp. cremoris during milk fermentation. BMC Genomics 2014 15:1054.

\section{Submit your next manuscript to BioMed Central and take full advantage of:}

- Convenient online submission

- Thorough peer review

- No space constraints or color figure charges

- Immediate publication on acceptance

- Inclusion in PubMed, CAS, Scopus and Google Scholar

- Research which is freely available for redistribution

Submit your manuscript at www.biomedcentral.com/submit
C) Biomed Central 